\title{
Pengaruh problem solving terhadap efektivitas inkuiri terbimbing dalam pembelajaran larutan penyangga ditinjau dari kemampuan argumentasi ilmiah peserta didik
}

\author{
Tsaniyatur Rizqi Nurul Laily, Suharti*, Siti Marfu'ah, Munthalib \\ Universitas Negeri Malang, Jl. Semarang No. 5 Malang, Jawa Timur, Indonesia \\ *Penulis korespondensi, Surel: suharti.fmipa@um.ac.id
}

Paper received: 01-06-2021; revised: 15-06-2021; accepted: 30-06-2021

\begin{abstract}
This study aims to determine a guided inquiry learning model enriched by problem solving can provide better results for students' scientific argumentation skills than guided-inquiry learning models. This study applies a quasi-experimental research design with post-test and a descriptive design. The sampling technique in this study applies a cluster random sampling technique. The data of the students' scientific argumentation skills is obtained from the ability of students to answer the descriptive questions of scientific argumentation. The instruments include learning instruments and measurement instruments. Descriptive analysis and a one-part t-test with the help of SPSS 25 for Windows are used in analyzing the data. The results show that guided inquiry learning model enriched by problem solving serves better results than guided inquiry models towards students' scientific argumentation skills in buffer solution material.
\end{abstract}

Keywords: Guided Inquiry; Problem Solving; Buffer Solution; Scientific Argument

\begin{abstract}
Abstrak
Penelitian ini bertujuan untuk mengetahui pengaruh pembelajaran inkuiri terbimbing yang diperkaya problem solving terhadap keterampilan argumentasi peserta didik pada materi larutan penyangga. Penelitian ini menggunakan rancangan penelitian eksperimental semu dengan pasca tes dan rancangan deskriptif. Teknik pengambilan sampel yang digunakan adalah cluster random sampling. Data keterampilan argumentasi ilmiah peserta didik diperoleh dari kemampuan peserta didik menjawab soal tes uraian keterampilan argumentasi ilmiah. Instrumen yang digunakan meliputi instrumen perlakuan dan instrumen pengukuran. Analisis data menggunakan analisis deskriptif dan uji-t satu pihak dengan bantuan program SPSS 25 for windows. Hasil penelitian menunjukkan bahwa model pembelajaran inkuiri terbimbing yang diperkaya problem solving memberikan hasil yang lebih baik dibandingkan model inkuiri terbimbing terhadap keterampilan argumentasi ilmiah peserta didik pada materi larutan penyangga.
\end{abstract}

Kata kunci: Inkuiri Terbimbing; Problem Solving; Larutan Penyangga; Keterampilan Argumentasi Ilmiah

\section{Pendahuluan}

Pendidikan sains pada dasarnya memiliki visi mempersiapkan peserta didik untuk memiliki pemahaman tentang sains dan teknologi, melalui pengembangan keterampilan berpikir, sikap dan upaya untuk mengelola lingkungan, serta mengatasi masalah dalam lingkungannya. Dalam jangka panjang visi pendidikan sains adalah memberikan kemampuan berpikir kiritis, logis, sistematis, bersikap kreatif, dan keterampilan lainnya yang merupakan dasar bekerja ilmiah yang perlu dikembangkan untuk memberikan bekal peserta didik menghadapi tantangan dalam masyarakat yang semakin kompetitif (Rustaman, 2005). Realisasi visi pendidikan sains didukung dengan kurikulum yang terus mengalami perbaikan dan penyempurnaan dalam menyesuaikan kebutuhan zaman dan perkembangan pendidikan. Pendekatan saintifik menjadi ciri utama pelaksanaan kurikulum 2013 yang saat ini berlaku dan diharapkan mampu memberikan kontribusi yang signifikan bagi perkembangan kualitas pendidikan. Pendekatan saintifik dimaksudkan untuk membangun keterampilan proses sains 
dalam memperoleh pengetahuan. Salah satu model pembelajaran yang disarankan adalah model inkuiri yang dapat mengembangkan kemampuan berpikir secara sistematis, logis, dan kritis. Model inkuiri yang biasa diterapkan di SMA adalah inkuiri terbimbing.

Beberapa penelitian menunjukkan adanya kesulitan yang dialami peserta didik dalam menguasai konsep-konsep larutan penyangga. Kesulitan yang dialami dapat disebabkan oleh berbagai faktor, diantaranya adalah (1) pengetahuan awal yang lemah; (2) permasalahan simbol dan rumus matematika; (3) kesulitan memahami konteks materi; (4) permasalahan menggenerelisasikan masalah (Parastuti, dkk., 2016). Faktor penyebab kesulitan peserta didik dalam menggeneralisasikan masalah pada larutan penyangga karena dibutuhkan sederet langkah atau tahap yang digunakan dalam memecahkan masalah.

Hasil penelitian Fatimah (2017) tentang implementasi pembelajaran inkuiri terbimbing pada materi larutan penyangga menyebutkan bahwa sebanyak 41,18\% peserta didik belum tuntas dalam pembelajaran materi larutan penyangga. Hal tersebut menunjukkan bahwa rendahnya pemahaman peserta didik dalam memecahkan suatu masalah. Walaupun model inkuiri dipandang sebagai model pembelajaran yang sesuai untuk mengkonstruksi pemahaman konsep peserta didik, model tersebut membutuhkan waktu yang banyak dalam perencanaan, pelaksanaan dan evaluasinya. Berbagai bentuk bantuan (schafolding) seringkali dipadukan dengan model inkuiri. Model inkuiri terbimbing pada umumnya yaitu guru membantu peserta didik untuk mendapatkan konsep, namun seringkali ditemukan peserta didik kurang mampu memanfaatkan konsep yang mereka peroleh untuk menyelesaikan masalah pada situasi yang berbeda.

Penelitian ini mencoba memberikan bantuan kepada peserta didik untuk melatih memanfaatkan konsep yang mereka peroleh melalui integrasi model problem solving dalam pembelajaran inkuiri terbimbing. Menurut Bodner, George \& Herron (2002), pada umumnya seseorang yang sukses dalam belajar kimia merupakan seseorang yang mampu mengembangkan kemampuan pemecahan masalah sendiri dan memanfaatkan kemampuannya untuk memecahkan masalah kimia. Menurut Hamalik (2002) problem soving merupakan suatu proses mental dan intelektual dalam menemukan masalah dan memecahkan berdasarkan data dan informasi yang akurat, sehingga dapat diambil kesimpulan yang tepat dan cermat.

Eemeren dan Grootendorst dalam Erduran (2008) menyatakan bahwa konteks argumentasi relevan untuk kelas sains karena berperan sebagai pembenaran pengetahuan (knowledge justification) dan argumentasi sebagai persuasi. Dalam sains, konstruksi pengetahuan terkait dengan pembenaran pengetahuan dan klaim yang harus terkait dengan jalur klausa logis atau data dan bukti dari berbagai sumber. Dengan demikian argumentasi dapat digunakan sebagai salah satu cara penilaian hasil belajar, terutama untuk validasi konstruk pengetahuan yang diperoleh oleh peserta didik. Argumentasi secara ilmiah dapat didefinisikan sebagai hubungan antara klaim dan data melalui justifikasi atau evaluasi pengetahuan berdasarkan bukti, baik secara empiris atau teoritis (Erduran, 2008).

\section{Metode}

Penelitian ini menggunakan rancangan penelitian eksperimental semu dengan pasca tes (Quasy Experimental Design Posttest Only) dan rancangan deskriptif. Rancangan penelitian eksperimental semu digunakan untuk mengetahui perbedaan keterampilan argumentasi peserta didik pada materi larutan penyangga antara kelas kontrol dan kelas eksperimen. 
Pada kelas eksperimen digunakan model pembelajaran inkuiri terbimbing yang diperkaya problem solving dan kelas kontrol menggunakan model pembelajaran inkuiri terbimbing.

Sampel penelitian dipilih dengan teknik cluster random sampling. Sampel yang digunakan pada penelitian ini yaitu kelas XI MIA 2 sebagai kelas eksperimen dan kelas XI MIA 3 sebagai kelas kontrol. Penelitian ini dilaksanakan di SMAN 1 Lawang Kabupaten Malang pada semester II tahun ajaran 2018/2019, yaitu dimulai pada minggu pertama hingga minggu keempat bulan Februari 2019.

Instrumen yang digunakan dalam penelitian ini adalah instrumen perlakuan dan instrumen pengukuran. Instrumen perlakuan terdiri dari silabus, RPP, dan LKPD yang sebelumnya telah di validasi oleh dua validator ahli. Instrumen pengukuran terdiri dari soal tes keterampilan argumentasi ilmiah peserta didik yang dirancang berdasarkan argumentasi menurut Puvirajah tahun 2007 dalam Lai (2012), lembar observasi dan angket. Soal tes keterampilan argumentasi ilmiah materi larutan penyangga divalidasi isi oleh dua validator ahli dan di uji coba pada peserta didik yang telah mempelajari materi larutan penyangga.

Teknik analisis data penelitian ini adalah analisis deskriptif dan analisis statistik. Analisis deskriptif digunakan untuk mengetahui keterlaksanaan proses pembelajaran pada kelas kontrol dan kelas eksperimen serta untuk mengetahui pendapat peserta didik terhadap pembelajaran menggunakan LKPD yang dikembangkan oleh Prastikasari (2018) berdasarkan sudut pandang peserta didik melalui angket. Analisis statistik diperoleh berdasakan hasil tes soal keterampilan argumentasi ilmiah peserta didik. Analisis statistik meliputi uji prasyarat, uji kesamaan dua rata-rata dan pengujian hipotesis. Uji prasyarat meliputi uji normalitas, uji homogenitas dan uji kesamaan dua rata-rata. Pengujian hipotesis dilakukan dengan metode statistik uji-t satu pihak dengan taraf signifikasi $\alpha=0,05$ dengan bantuan SPSS 25 for Windows.

\section{Hasil dan Pembahasan}

\section{HASIL}

Data persentase keterlaksanaan pembelajaran dengan model inkuiri terbimbing yang diperkaya problem solving pada kelas eksperimen dan pembelajaran dengan pendekatan inkuiri terbimbing pada kelas kontrol dapat dilihat pada Tabel 4.1.

Tabel 4.1 Data Persentase Keterlaksanaan Proses Pembelajaran

\begin{tabular}{|c|c|c|c|c|}
\hline \multirow{3}{*}{ Pertemuan } & \multicolumn{4}{|c|}{ Keterlaksanaan Proses Pembelajaran (\%) } \\
\hline & \multicolumn{2}{|c|}{ Eksperimen (XI MIA 2) } & \multicolumn{2}{|c|}{ Kontrol (XI MIA 3) } \\
\hline & Observer I & Observer II & Observer I & Observer II \\
\hline I & 100 & 96,65 & 85,71 & 85,71 \\
\hline II & 95,24 & 95,24 & 100 & 100 \\
\hline III & 95,24 & 90,48 & 89,47 & 94,74 \\
\hline
\end{tabular}

Berdasarkan data pada Tabel 4.1 di atas dapat dilihat nilai yang diberikan oleh masingmasing observer pada proses pembelajaran setiap pertemuan pada masing-masing kelas. Kesesuaian penilaian yang diperoleh dari kedua observer cukup tinggi. Data rata-rata dan kriteria keterlaksanaan proses pembelajaran pada masing-masing kelas dapat dilihat pada Tabel 4.2 . 
Tabel 4.2 Data Persentase Rata-rata dan Kriteria Keterlaksanaan Proses Pembelajaran

\begin{tabular}{lllll}
\hline & \multicolumn{3}{l}{ Rata-rata Keterlaksanaan Proses Pembelajaran (\%) } \\
\cline { 2 - 5 } Pertemuan & Eksperimen & Kriteria & Kontrol & Kriteria \\
\hline I & 98,32 & Sangat baik & 85,71 & Sangat baik \\
II & 95,24 & Sangat baik & 100 & Sangat baik \\
III & 92,86 & Sangat baik & 92,11 & Sangat baik \\
Rata-rata & 95,47 & Sangat baik & 92,61 & Sangat baik \\
\hline
\end{tabular}

Berdasarkan Tabel 4.2 dapat dilihat bahwa rata-rata nilai keterlaksanaan proses pembelajaran pada peserta didik di kedua kelas termasuk dalam kategori terlaksana dengan sangat baik. Hal ini dapat dilihat dari persentase rata-rata keterlaksanaan proses pembelajaran dari ketiga pertemuan pada setiap kelas yaitu pada kelas eksperimen sebesar 95,47\% dan pada kelas kontrol sebesar 92,61\%.

Data kemampuan awal peserta didik diperoleh dari nilai hasil Ujian Semester Ganjil yang terdiri dari materi hidrokarbon, termokimia, laju reaksi, dan kesetimbangan kimia kelas XI MIA SMAN 1 Lawang. Data kemampuan awal peserta didik dapat dilihat pada Tabel 4.3.

\section{Tabel 4.3 Data Kemampuan Awal Peserta Didik}

\begin{tabular}{lllll}
\hline \multirow{2}{*}{ Kelas } & $\begin{array}{l}\text { Jumlah } \\
\text { Peserta Didik }\end{array}$ & $\begin{array}{l}\text { Nilai } \\
\text { Terendah }\end{array}$ & $\begin{array}{l}\text { Nilai } \\
\text { Tertinggi }\end{array}$ & Rata-rata \\
& 36 & 32,50 & 82,50 & 55,69 \\
Eksperimen & 36 & 22,50 & 87,50 & 51,67 \\
Kontrol & 36 & & & \\
\hline
\end{tabular}

Tabel 4.3 menunjukkan bahwa kemampuan awal peserta didik pada kedua kelas tidak memiliki perbedaan yang signifikan. Rata-rata kemampuan awal peserta didik kelas eksperimen sebesar 55,69 dan kelas kontrol sebesar 51,67.

Analisis data kemampuan awal peserta didik dilakukan dengan uji Independent Sample tTest atau uji kesamaan dua rata-rata dengan bantuan program SPSS 25 for windows. Sebelum dilakukaan uji kesamaan dua rata-rata terlebih dahulu dilakukan uji prasyarat yaitu uji normalitas dan uji homogenitas. Hasil uji normalitas kemamuan awal peserta didik disajikan pada Tabel 4.4.

Tabel 4.4 Hasil Uji Normalitas Kemampuan Awal Peserta Didik

\begin{tabular}{llll}
\hline Kelas & Nilai Signifikansi & A & Kesimpulan \\
\hline Eksperimen & 0,756 & 0,05 & Normal \\
Kontrol & 0,723 & 0,05 & Normal \\
\hline
\end{tabular}

Tabel 4.4 menunjukkan bahwa uji normalitas data kemampual awal peserta didik pada kedua kelas tersebut memiliki nilai signifikansi $\alpha>0,05$, yaitu diperoleh hasil pada kelas eksperimen dengan nilai signifikansi sebesar 0,756 dan kelas kontrol sebesar 0,723. Berdasarkan hasil tersebut dapat disimpulkan bahwa data kemampuan awal peserta didik kelas eksperimen dan kontrol terdistribusi secara normal. Hasil uji homogenitas kemampuan awal peserta didik dapat dilihat pada Tabel 4.5. 
Tabel 4.5 Hasil Uji Homogenitas Data Kemampuan Awal Peserta Didik

\begin{tabular}{lllll}
\hline Kelas & Nilai Uji F Levene & Nilai Signifikansi & $\alpha$ & Kesimpulan \\
\hline $\begin{array}{l}\text { Eksperimen } \\
\text { Kontrol }\end{array}$ & 0.714 & 0,401 & 0,05 & Homogen \\
\hline
\end{tabular}

Tabel 4.5 menunjukkan bahwa data kemampuan awal peserta didik pada kelas eksperimen dan kontrol memiliki varian yang homogen karena nilai signifikansi lebih besar dari 0,05 yaitu sebesar 0,401. Uji kesamaan dua rata-rata bertujuan untuk mengetahui kesamaan rata-rata nilai kemampuan awal peserta didik. Uji yang digunakan adalah uji-t Independent Sample t-Test dengan taraf signifikansi 0,05 dengan program SPSS 25 for windows. Hasil uji kesamaan dua rata-rata kemampuan awal peserta didik dapat dilihat pada Tabel 4.6.

Tabel 4.6 Hasil Uji Kesamaan Dua Rata-rata

\begin{tabular}{llll}
\hline Kelas & Nilai Signifikansi & $\alpha$ & Kesimpulan \\
\hline Eksperimen & 0,998 & 0,05 & $\begin{array}{l}\text { Tidak ada perbedaan } \\
\text { kemampuan awal peserta } \\
\text { didik }\end{array}$ \\
\hline
\end{tabular}

Tabel 4.6 menunjukkan bahwa tidak ada perbedaan kemampuan awal peserta didik pada kelas eksperimen dan kelas kontrol.

Hasil tes keterampilan argumentasi ilmiah peserta didik dapat dilihat pada Tabel 4.7.

Tabel 4.7 Hasil Tes Keterampilan Argumentasi Ilmiah Peserta Didik

\begin{tabular}{lllll}
\hline Kelas & $\begin{array}{l}\text { Jumlah Peserta } \\
\text { Didik }\end{array}$ & $\begin{array}{l}\text { Nilai } \\
\text { Terendah }\end{array}$ & Nilai Tertinggi & Rata-rata \\
\hline Eksperimen & 34 & 37.14 & 88,57 & 63,11 \\
Kontrol & 34 & 37.14 & 85,71 & 57,14 \\
\hline
\end{tabular}

Tabel 4.7 menunjukkan bahwa nilai rata-rata keterampilan argumentasi ilmiah kelas eksperimen $(63,11)$ lebih tinggi dibanding kelas kontrol $(57,14)$. Keterampilan argumentasi ilmiah peserta didik diukur menggunakan lima soal uraian. Kelima soal tersebut melatih peserta didik untuk menganalisis dan mengevaluasi data serta memberikan penjelasan berdasarkan claim yang dibuat sesuai dengan keterampilan argumentasi ilmiah berdasarkan Puvirajah tahun 2007 dalam Lai (2012).

Persentase kualitas struktur argumentasi ilmiah peserta didik kelas eksperimen dan kelas kontrol untuk kriteria pencapaian kualitas struktur argumentasi tipe I, tipe II, dan tipe III disajikan pada Tabel 4.8 .

Tabel 4.8 Persentase Hasil Kualitas Struktur Argumentasi Ilmiah Peserta Didik

\begin{tabular}{|c|c|c|c|}
\hline \multirow{2}{*}{ Kelas } & \multicolumn{3}{|c|}{ Pencapaian Kualitas Struktur Argumentasi Peserta Didik (\%) } \\
\hline & Tipe I & Tipe II & Tipe III \\
\hline Eksperimen & 7,1 & 15,3 & 77,6 \\
\hline
\end{tabular}


Berdasarkan Tabel 4.8, persentase kualitas struktur argumentasi ilmiah peserta didik kelas eksperimen mencapai tipe I (proficient to advanced) dan tipe II lebih tinggi daripada kelas kontrol, sedangkan tipe III (insufficient to basic) lebih tinggi kelas kontrol daripada kelas eksperimen. Hasil tersebut membuktikan bahwa pada kelas eksperimen mencapai kualitas argumentasi tertinggi (tipe I) daripada kelas kontrol. Adanya perbedaan persentase tersebut menunjukkan bahwa terdapat variasi pencapaian kualitas struktur argumentasi ilmiah peserta didik pada masing-masing kelas.

Persentase kredibilitas ilmiah peserta didik kelas eksperimen dan kelas kontrol berdasarkan tingkatan kredibilitas disajikan pada Tabel 4.9.

Tabel 4.9 Persentase Hasil Kredibilitas Ilmiah Peserta Didik

\begin{tabular}{lllll}
\hline \multirow{3}{*}{ Kelas } & \multicolumn{3}{l}{ Pencapaian Kredibilitas Ilmiah Peserta Didik (\%) } \\
\cline { 2 - 5 } & Tidak Kredibel & Kredibilitas & Kredibilitas & Kredibilitas \\
& $(0)$ & Rendah (1-2) & Sedang (3) & Tinggi (4-5) \\
\hline Eksperimen & 4,1 & 31,8 & 20 & 44,1 \\
Kontrol & 4,7 & 44,7 & 15,3 & 35,3 \\
\hline
\end{tabular}

Tabel 4.9 menunjukkan bahwa persentase kredibilitas ilmiah peserta didik kelas eksperimen mencapai kredibilitas tinggi dan sedang lebih besar daripada kelas kontrol, untuk kredibilitas rendah dan tidak kredibel lebih besar kelas kontrol daripada kelas eksperimen. Berdasarkan hasil tersebut dapat diketahui adanya variasi persentase kredibilitas argumentasi ilmiah peserta didik. Sehingga dari data perolehan kualitas struktur argumentasi serta kredibilitas argumentasi peserta didik, kelas eksperimen memiliki keterampilan argumentasi ilmiah lebih tinggi dalam menjawab soal tes dengan komponen argumentasi ilmiah meliputi claim, evidence, dan explanation.

Keterampilan argumentsi ilmiah peserta didik di analisis statistik dengan menggunakan uji-t yang sebelumnya telah di uji normalitas dan uji homogenitas untuk membuktikan bahwa keterampilan argumentasi ilmiah peserta didik kelas eksperimen memberikan hasil yang lebih baik daripada kelas kontrol. Hasil uji normalitas keterampilan argumentasi ilmiah peserta didik disajikan pada Tabel 4.10 .

Tabel 4.10 Hasil Uji Normalitas Keterampilan Argumentasi Ilmiah Peserta Didik

\begin{tabular}{llll}
\hline Kelas & Nilai Signifikansi & $\alpha$ & Kesimpulan \\
\hline Eksperimen & 0,200 & 0,05 & Normal \\
Kontol & 0,154 & 0,05 & Normal \\
\hline
\end{tabular}

Dari Tabel 4.10 diperoleh hasil keterampilan argumentasi ilmiah peserta didik kelas eksperimen dengan signifikansi sebesar 0,200 dan kelas kontrol sebesar 0,154. Berdasarkan nilai tersebut data keterampilan argumentasi ilmiah peserta didik kelas eksperimen dan kelas kontrol terdistribusi secara normal.

Hasil uji homogenitas keterampilan argumentasi ilmiah peserta didik disajikan pada Tabel 4.11. 
Tabel 4.11 Hasil Uji Homogenitas Keterampilan Argumentasi Ilmiah Peserta Didik

\begin{tabular}{llll}
\hline Kelas & Nilai Signifikansi & $\alpha$ & Kesimpulan \\
\hline $\begin{array}{l}\text { Eksperimen } \\
\text { Kontrol }\end{array}$ & 0,115 & 0,05 & Homogen \\
\hline
\end{tabular}

Tabel 4.11 menunjukkan bahwa keterampilan argumentasi ilmiah peserta didik kelas eksperimen dan kelas kontrol memiliki nilai signifikansi 0,115. Nilai signifikansi lebih besar dari 0,05. Dapat disimpulkan bahwa kelas eksperimen dan kelas kontrol memiliki varian yang homogen.

Uji-t satu pihak dengan taraf signifikansi 0,05 digunakan sebagai uji hipotesis dengan bantuan program SPSS 25 for windows. Hasil uji-t satu pihak data keterampilan argumentasi ilmiah peserta didik kelas eksperimen dan kelas kontrol disajikan pada Tabel 4.12.

Tabel 4.12 Hasil Uji-t Data Keterampilan Argumentasi Ilmiah Peserta Didik

\begin{tabular}{llll}
\hline Variabel & Nilai thitung $_{\text {Nilai }}$ & tabel $_{\text {tam }}$ & Kesimpulan \\
\hline $\begin{array}{l}\text { Keterampilan argumentasi ilmiah } \\
\text { peserta didik }\end{array}$ & 2,504 & 1,692 & $\begin{array}{l}\mathrm{H}_{0} \text { ditolak dan } \\
\mathrm{H}_{1} \text { diterima }\end{array}$ \\
\hline
\end{tabular}

Berdasarkan Tabel 4.12 t hitung memiliki nilai lebih besar daripada t tabel, yaitu 2,504 $>$ 1,692 sehingga $\mathrm{H}_{0}$ ditolak dan $\mathrm{H}_{1}$ diterima. Oleh karena itu dapat disimpulkan bahwa pembelajaran dengan pendekatan inkuiri terbimbing yang diperkaya dengan problem solving memberikan hasil yang lebih baik dibandingkan pembelajaran dengan pendekatan inkuiri terbimbing terhadap kemampuan argumentasi ilmiah peserta didik.

Persentase persepsi peserta didik terhadap LKPD berbasis inkuiri terbimbing yang diperkaya problem solving dapat dilihat pada Tabel 4.13.

Tabel 4.13 Persentase Persepsi Peserta Didik Terhadap Isi dan Pembelajaran Menggunakan LKPD Berbasis Inkuiri Terbimbing yang Diperkaya Problem Solving

\begin{tabular}{lll}
\hline Aspek & Rata-rata & Kriteria \\
\hline $\begin{array}{l}\text { Isi dan pembelajaran menggunakan LKPD } \\
\text { berbasis inkuiri terbimbing yang diperkaya } \\
\text { problem solving }\end{array}$ & $81 \%$ & Sangat Baik \\
\hline
\end{tabular}

Hasil angket persepsi peserta didik terhadap isi dan pembalajaran menggunakan LKPD berbasis inkuiri terbimbing yang diperkaya problem solving menunjukkan kriteria sangat baik.

\section{PEMBAHASAN}

Berdasarkan Tabel 4.2, persentase keterlaksanaan proses pembelajaran pertemuan pertama pada kelas eksperimen sebesar 98,32 \% sehingga termasuk dalam kriteria terlaksana dengan sangat baik. Proses yang tidak terlaksana adalah terdapat kelompok yang tidak menganalisis kecenderungan pengaruh penambahan asam, basa dan air pada larutan penyangga, sehingga kelompok tersebut kebingungan ketika ditanyakan mengenai pengaruh penambahan asam, basa maupun air ke dalam larutan penyangga. Namun kelompok lain 
membantu menjelaskan mengenai pengaruh penambahan asam, basa maupun air ke dalam larutan penyangga, sehingga tidak ada dampak untuk mengikuti pembelajaran yang selanjutnya. Persentase keterlaksanaan proses pembelajaran pada kelas kontrol di pertemuan pertama sebesar $85,71 \%$ dan tergolong dalam kriteria terlaksana dengan sangat baik. Beberapa proses yang tidak terlaksana adalah peserta didik mengkaji literatur tentang perhitungan $\mathrm{pH}$ larutan penyangga, peserta didik menjelaskan prinsip kerja larutan penyangga, dan kesimpulan yang disampaikan oleh peserta didik. Hal tersebut menyebabkan pada pertemuan selanjutnya guru harus mengulang pembelajaran mengenai prinsip kerja larutan penyangga, dan memastikan peserta didik memahami pembelajaran yang telah dilakukan pada pertemuan pertama.

Persentase keterlaksanaan proses pembelajaran pertemuan ke dua pada kelas eksperimen sebesar 95,24\% sehingga termasuk dalam kriteria terlaksana dengan sangat baik. Proses pembelajaran yang tidak terlaksana adalah penyampaian kesimpulan oleh peserta didik. Hal tersebut dapat terjadi karena keterbatasan waktu, sehingga guru tidak menunjuk beberapa peserta didik untuk menyampaikan kesimpulannya. Untuk menghindari hal tersebut maka perlu adanya pengaturan waktu yang baik. Sedangkan pada kelas kontrol terlaksana dengan sangat baik yaitu $100 \%$.

Persentase keterlaksanaan proses pembelajaran pertemuan ke tiga pada kelas eksperimen yaitu 92,86\% dan termasuk kriteria sangat baik. Proses pembelajaran yang tidak terlaksana adalah membuat grafik perubahan nilai $\mathrm{pH}$ pada dua larutan penyangga dengan konsentrasi yang berbeda. Hal ini dapat terjadi karena pada LKPD telah digambarkan grafik perubahan nilai $\mathrm{pH}$, sehingga peserta didik hanya menganalisis faktor yang mempengaruhi kapasitas penyangga melalui grafik yang sudah tersedia. Persentase keterlaksanaan pembelajaran kelas kontrol sebesar $92,11 \%$ dan termasuk dalam kriteria sangat baik. Proses pembelajaran yang tidak terlaksana pada kelas kontrol ini adalah guru tidak me-review pembelajaran pada pertemuan yang sebelumnya dan peserta didik tidak membuat grafik perubahan nilai pH pada dua larutan penyangga dengan konsentrasi yang berbeda. Hal tersebut tidak berdampak pada penyampaian materi yang dilakukan pada pertemuan ketiga, karena peserta didik dapat membuka catatan maupun LKPD.

Hasil ulangan akhir bab materi larutan penyangga berupa soal uraian tes argumentasi digunakan sebagai data keterampilan argumentasi ilmiah peserta didik. Uji homogenitas dan normalitas yang digunakan sebagai prasyarat analisis menunjukkan bahwa data terdistribusi normal dan memiliki varian homogen. Hasil uji hipotesis menggunakan uji-t pada Tabel 4.12 menghasilkan nilai $t$ hitung lebih besar daripada $t$ tabel, yaitu 2,504 $>1,692$ sehingga $\mathrm{H}_{0}$ ditolak dan $\mathrm{H}_{1}$ diterima. Berdasarkan hal tersebut dapat disimpulkan bahwa secara statistik pembelajaran dengan inkuiri terbimbing yang diperkaya dengan problem solving memberikan hasil yang lebih baik dibandingkan pembelajaran dengan inkuiri terbimbing terhadap kemampuan argumentasi ilmiah peserta didik pada materi larutan penyangga. Peserta didik kelas eksperimen memiliki nilai rata-rata kelas lebih tinggi yaitu 63,11 dibandingkan kelas kontrol yang memiliki rata-rata kelas 57,14. Nilai rata-rata keterampilan argumentasi peserta didik kelas eksperimen dan kelas kontrol lebih tinggi daripada nilai ratarata kemampuan awal. Hal tersebut menunjukkan bahwa integrasi problem solving model polya ke dalam model inkuiri terbimbing mengindikasi peningkatan kemampuan pemahaman peserta didik berdasarkan kemampuan argumentasi ilmiah pada materi larutan penyangga. Namun rendahnya perbedaan rata-rata kemampuan awal peserta didik kelas 
eksperimen dan kelas kontrol dengan hasil tes argumentasi larutan penyangga masih menunjukkan bahwa diperlukan perbaikan pembelajaran untuk meningkatkan kemampuan argumentasi peserta didik.

Keterampilan argumentasi peserta didik berdasarkan kualitas struktur argumentasi ilmiah mencapai tipe I (baik - sangat baik) sebanyak 7,1\% untuk kelas eksperimen dan 2,4\% untuk kelas kontrol. Tipe II (cukup - baik) sebanyak 15,3\% kelas eksperimen dan 11,7\% kelas kontrol, sedangkan mencapai tipe III (kurang - cukup) sebanyak 77,6\% kelas eksperimen dan 85,9\% kelas kontrol. Berdasarkan nilai tersebut dapat digolongkan bahwa kedua kelas mencapai tipe III yang cukup tinggi. Hal itu menandakan bahwa pengetahuan peserta didik terhadap keterampilan argumentasi ilmiah masih tergolong kurang sampai cukup, akan tetapi kelas eksperimen mencapai tipe I dengan kriteria baik sampai sangat baik lebih tinggi dibandingkan dengan kelas kontrol. Secara umum, penyebab rendahnya rata-rata nilai argumentasi peserta didik adalah peserta didik belum pernah menerapkan pembelajaran yang menitikberatkan pada kemampuan argumentasi ilmiah sehingga ketika peserta didik dihadapkan dengan beberapa masalah dan menyelesaikannya dengan berargumentasi masih terdapat beberapa kesulitan.

Hasil analisis kredibilitas ilmiah peserta didik menunjukkan bahwa kelas eksperimen mencapai nilai kredibilitas tinggi 44,1\% dan kelas kontrol sebesar 35,3\%. Hal tersebut menunjukkan bahwa kelas yang dibelajarkan menggunakan inkuiri terbimbing yang diperkaya problem solving memiliki nilai kredibilitas lebih tinggi dibandingkan dengan kelas yang dibelajarkan menggunakan inkuiri terbimbing saja.

Berdasarkan hasil rekapan angket pada kelas eksperimen menunjukkan bahwa persepsi peserta didik terhadap isi dan pembelajaran menggunakan LKPD berbasis inkuiri terbimbing yang dipekaya problem solving sebesar 81\% dengan kriteria sangat baik. Penilaian terhadap isi dan pembelajaran menggunakan LKPD berbasis inkuiri terbimbing yang diperkaya problem solving ini mendapat respon yang positif meskipun dalam pembelajarannya terdapat beberapa kekurangan. Beberapa peserta didik menyatakan bahwa terdapat pertanyaan yang kurang jelas, sulit untuk dipahami, dan materi pembelajaran kurang runtut tidak seperti yang ada pada buku pegangan peserta didik. Solusi untuk meminimalisir kekurangan dari LKPD adalah memperbaiki tatanan bahasa yang ada pada LKPD agar lebih mudah dipahami peserta didik, pertanyaan-pertanyaan yang menuntun peserta didik untuk mendapatkan suatu konsep sebaiknya dari pertanyaan yang mudah hingga pertanyaan yang sulit agar peserta didik tidak kebingungan dalam mecari jawaban, serta ilustrasi yang digunakan sebaiknya lebih nyata dan dapat ditemui dikehidupan seharihari.

\section{Simpulan}

Berdasarkan hasil penelitian yang berkaitan dengan pembelajaran larutan penyangga dengan menggunakan model pembelajaran inkuiri terbimbing yang diperkaya problem solving di SMAN 1 Lawang, kesimpulan yang diperoleh yaitu keterlaksanaan proses pembelajaran kelas yang menggunakan model inkuiri terbimbing yang diperkaya problem solving dan kelas yang menggunakan model inkuiri terbimbing pada materi larutan penyangga kelas XI MIA SMAN 1 Lawang memiliki rata-rata sebesar 95,47\% dan 92,61\%, sehingga menunjukkan bahwa pembelajaran sudah terlaksana dengan sangat baik. Model pembelajaran inkuiri terbimbing yang diperkaya problem solving memberikan hasil yang 
lebih baik daripada model pembelajaran inkuiri terbimbing terhadap kemampuan argumentasi ilmiah peserta didik pada materi larutan penyangga kelas XI SMAN 1 Lawang. Jika dilihat dari kualitas dan kredibilitas argumentasi peserta didik pada materi larutan penyangga, kelas yang dibelajarkan dengan model inkuiri terbimbing yang diperkaya problem solving memiliki nilai kualitas dan kredibilitas yang lebih tinggi dibandingkan kelas yang dibelajarkan dengan model inkuiri terbimbing yaitu $44,1 \%$ dan $35,3 \%$. Penilaian terhadap isi dan pembelajaran menggunakan LKPD berbasis inkuiri terbimbing yang diperkaya problem solving ini mendapat respon yang positif oleh peserta didik dan memiliki kriteria sangat baik yaitu $81 \%$.

\section{Daftar Rujukan}

Bodner, G. M., \& Herron, J. D. (2002). Problem-solving in chemistry. In Chemical education: Towards researchbased practice (pp. 235-266). Springer, Dordrecht.

Erduran, S. (2008). Methodological foundations in study of argumentation in science education. Erduran S., Jimenez Aleixandre MP (Editörler).(2008). Argumentation in science education-perspectives from classroom based research. UK.

Fatimah, A. (2017). Implementasi pembelajaran model inkuiri terbimbing pada materi larutan penyangga di SMAN 02 Batu. SKRIPSI Jurusan Kimia-Fakultas MIPA UM.

Hamalik, O. (2002). Perencanaan pengajaran berdasarkan pendekatan sistem, Jakarta: PT. Bumi Aksara, Cet. I.

Lai, M. C. (2012). Nature of science knowledge and scientific argumentation skills in Taiwanese college biology students (Doctoral dissertation, The Ohio State University).

Parastuti, W. I., Suharti, S., \& Ibnu, S. (2016). Miskonsepsi siswa pada materi larutan buffer. Jurnal pendidikan: teori, penelitian, dan pengembangan, 1(12), 2307-2313.

Rustaman, N. Y. (2005, July). Perkembangan penelitian pembelajaran berbasis inkuiri dalam pendidikan sains. In Makalah dipresentasikan dalam Seminar Nasional II Himpunan Ikatan Sarjada dan Pemerhati Pendidikan IPA Idonesia Bekerjasama dengan FPMIPA. Universitas Pendidikan Indonesia, Bandung (pp. 22-23). 